\title{
Glossa
}

a journal of general linguistics

\section{Developing the feature inventory of the inherent}

cases

\section{JANE MIDDLETON (1)}

\section{] $\mathrm{u}$ [ubiquity press}

\begin{abstract}
In this squib I propose a modification to Radkevich's (2010) analysis of the locative cases, such that the privative features [source] and [goal] replace Radkevich's binary features [ \pm motion] and [ \pm source]. I argue that these changes improve Radkevich's analysis in three ways. The first improvement is empirical; they allow her system to account for the data of Kunimaipa, a language spoken in Papua New Guinea, which it presently cannot account for. The second improvement is also empirical; the analysis now predicts the absence of the unattested Ablative-Allative syncretism, which is not explained by alternative analyses. The final improvement is theoretical; a system employing privative features is to be preferred over one with binary features, because it is simpler (Occam's razor).
\end{abstract}

CORRESPONDING AUTHOR:

\section{Jane Middleton}

University College London, 2 Wakefield Street, London, WC1N 1PF, GB

hannah.middleton.11@ucl. ac.uk

\section{KEYWORDS:}

inherent case; locative cases; Distributed Morphology

TO CITE THIS ARTICLE: Middleton, Jane. 2021. Developing the feature inventory of the inherent cases. Glossa: a journal of general linguistics 6(1): 68. 1-11. DOI: https://doi. org/10.5334/gjgl.933 


\section{Introduction}

The three most common locative cases are Locative (at location $x$ ), Allative (to location $x$ ), and Ablative (from location $x$ ). These cases have been reported to show three patterns of syncretism (Radkevich 2010: §4.2), which are illustrated in (1) for the Algonquian language Plains Cree (spoken in Canada), the Californian language Palaihnihan, and the Pama-Nyungan language Bunganditj (spoken in Australia). Syncretism can occur between all three cases, as in Plains Cree, between the Locative and Ablative cases, as in Palaihnihan, or between the Locative and Allative cases, as in Bunganditj (1).

Syncretism in the locative cases of Plains Cree, Palaihnihan and Bunganditj

\begin{tabular}{lllllll}
\hline \multicolumn{2}{c}{ Plains Cree } & \multicolumn{2}{c}{ Palaihnihan } & \multicolumn{2}{c}{ Bunganditj } \\
\hline$-i k h$ & ABLATIVE & $-m-$ & ABLATIVE & $-a n$ & ABLATIVE \\
$-i k h$ & LOCATIVE & $-m-$ & LOCATIVE & $-u$ & LOCATIVE \\
$-i k h$ & ALLATIVE & $-t-$ & ALLATIVE & $-u$ & ALLATIVE \\
\hline \multicolumn{2}{l}{ Dahlstrom 1991} & \multicolumn{2}{c}{ Broadbent 1964 } & \multicolumn{2}{c}{ Blake 2003} \\
\hline
\end{tabular}

Following a long line of scholars (e.g. Jakobson 1962; Halle \& Marantz 1993; Harley 2008; Caha 2009; Radkevich 2010; Bobaljik 2012), I take the syncretism of two items to indicate that they share a common underlying feature. The analysis in this squib is presented within the theoretical frameworks of Distributed Morphology (Halle \& Marantz 1993) and Minimalism (Chomsky 1993; 1995). In these frameworks, feature bundles constitute the terminal nodes of syntactic trees, and after the syntax has sent the structure to Spell Out, the final tree is fed to the articulatory and conceptual interfaces, where the feature bundles receive their phonological forms and semantic meaning.

In order for principled syncretism to occur, certain morphemes must have at least one feature in common. Suppose Node A bears the features [F G], while Node B bears [G H]. Syncretism will occur if there is no exponent that realises [F G] or [G H], but only one for the feature [G]. This morpheme is thus the maximally specified one for both feature bundles (the Maximal Subset Principle, Kiparsky 1973; Halle \& Marantz 1993), and syncretism will occur.

The most comprehensive analysis of the locative cases to date is Radkevich 2010. Radkevich analyses the morphology of locative case markers in 111 languages, and shows that these three cases are internally complex, being composed of a feature denoting 'location', and a feature bundle containing further information about the presence or absence of motion to or from the location, [ \pm motion], and whether or not that location is the source of any motion, $[ \pm$ source]. Throughout this squib I will refer to Radkevich's analysis as the Allative-centred analysis, for reasons that will become clear in $\S 2$.

The arguments presented in this squib depend on the case morphology of four Papuan languages of New Guinea reported in Foley (1986) and Harbour (2007b): Kunimaipa, Iatmul, Kewa, and Dani. In these languages, it frequently happens that the only inflectional category for nouns is case. The Papuan languages typically denote abstract relationships such as 'instrument' or 'beneficiary' with bound case affixes, and express more concrete locational notions such as above, under, beside, inside and along with postpositions (Foley 1986: 93). The most basic DP roles in sentences, those of subject and object, are typically marked with verbal agreement, rather than case suffixes or word-order (Foley 1986: 94). For the purposes of this squib, I focus exclusively on the morphology of bound case affixes, and leave an analysis of the relationship between bound case affixes, postpositions and verbal agreement for future work.

In the present squib, I argue for two modifications to Radkevich's analysis. I propose firstly that, while the Allative-centred analysis accounts for all the data in Radkevich's survey, data from Kunimaipa is also compatible with a different logically possible arrangement of the cases (Harbour 2007b), which I will call the Locative-centred analysis (§2). Secondly, I propose that the syncretism patterns of Iatmul, Kewa, and Dani support an analysis in which the features that underlie the locative Cases are privative, following Occam's Razor (§3). Furthermore, this simplification is only possible if we adopt the Locative-centred arrangement of the cases, and it correctly predicts that 
the Ablative and Allative cases will never be syncretic to the exclusion of the Locative case, a result found in Radkevich's (2010) survey, but not predicted by her analysis. I conclude in $\S 4$.

\section{Logically possible orders of the Cases}

In this section I demonstrate that there are three logically possible orderings of the locative cases, and that the data from the Papuan language of New Guinea, Kunimaipa, is only compatible with two of them. Consider the data in (2).

$$
\text { Kunimaipa cases }
$$

\begin{aligned} \hline Kunimaipa \\ \hline$-t i \quad$ Allative \\ - ha $\quad$ Locative \\ -ha-nanga $\quad$ Ablative \\ -nanga $\quad$ Instr. \\ \hline Foley 1986: 101\end{aligned}

(3)

$$
\text { Feature chart for the Locative-centred analysis }
$$

\begin{tabular}{|l|}
\hline -location \\
\hline +location \\
\hline
\end{tabular}

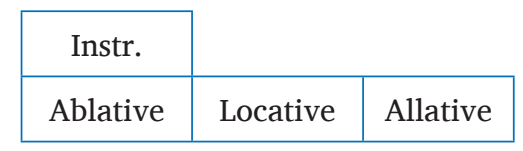

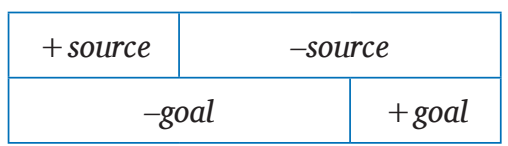

In this squib, I propose that the locative cases should be arranged as seen in the chart in (3), where the Locative case is flanked by the Ablative and Allative cases. I will call this the Locativecentred analysis of the cases. The two features that complement [ \pm location] are $[ \pm$ source] and [ \pm goal]. I assume that nothing can be simultaneously both a source and a goal; the feature bundle $[+$ source + goal] is impossible.

The feature bundle for Locative case in this analysis is [+location-source -goal]. Thus, the Locative case denotes a location which is neither a source nor a goal. The feature bundle for the Ablative case is [+location + source-goal]; it marks a location, which is a source and not a goal location. The feature bundle of the Allative case is the Ablative case's logical counterpart: [+location + goal-source]; the Allative case denotes a goal location.

There is another case presented here: Instrumental. The Instrumental case marks the tool used to complete an action, such as the knife in the sentence I cut the cake with a knife. I have assigned the Instrumental case the feature bundle [-location + source]; this is motivated by the morphology of Kunimaipa (Harbour 2007b). ${ }^{1}$ The exponents the Locative-centred analysis requires for Kunimaipa are given in (4).

\section{Vocabulary Items for Kunimaipa in the Locative-centred analysis}

\begin{tabular}{rll}
\hline Kunimaipa & \\
\hline$[+$ location + goal $]$ & $\Leftrightarrow$ & -ti \\
{$[+$ location $]$} & $\Leftrightarrow$ & -ha \\
{$[+$ source $]$} & $\Leftrightarrow$ & -nanga \\
\hline
\end{tabular}

1 That the Instrumental case is marked for [+source] is not as implausible as it might at first seem; the Instrumental case is often syncretic with Ablative, as is the case with the exponent met in the Algic language Yurok (Robins 1958), -inda in the Dravidian language Kannada (Sridhar 1990), and across all declensions in Latin (Calabrese 2008). 
Beginning with the morpheme for the Allative case, we can see that the exponent -ti is a portmanteau, spelling out $[+$ location + goal]. The morpheme -ha is present in both the Locative and Ablative cases; their shared features are [+location -goal], but in anticipation of the discussion of binary and privative features in §3, I will give -ha as spelling out [+location]. Finally, we have the morpheme -nanga; this is found in both the Ablative and Instrumental cases. Since the Instrumental case marks a tool and not a location (and since we already know that [+location] is spelled out by -ha), -nanga must spell out [+source]. Hence my conclusion (as Harbour 2007b concluded before me) that the feature bundle for the Instrumental case is [-location + source].

In this arrangement of the cases, Ablative and Locative share a property; that of not denoting a goal location, and the Locative and Allative cases denote locations that aren't a source. The Ablative and Allative cases have no property but 'location' in common. The Locative-centred analysis thus accounts for the syncretisms in (1) with the exponents in (5) (where loc = location and sou $=$ source).

(5)

Exponents for the languages in (1) in the Locative-centred analysis

\begin{tabular}{|c|c|c|c|c|c|c|c|c|c|}
\hline \multicolumn{3}{|c|}{ Plains Cree } & \multicolumn{4}{|c|}{ Palaihnihan } & \multicolumn{3}{|c|}{ Bunganditj } \\
\hline \multirow[t]{2}{*}[+loc]{} & $\Leftrightarrow$ & $-i k h$ & {$[+l o c$} & + goal] & $\Leftrightarrow$ & $-t-$ & {$[+l o c+s o u]$} & $\Leftrightarrow$ & -an \\
\hline & & & & {$[+l o c]$} & $\Leftrightarrow$ & $-m-$ & {$[+l o c]$} & $\Leftrightarrow$ & $-\mathrm{u}$ \\
\hline
\end{tabular}

The Locative-centred analysis is not the only logically possible arrangement of the cases. Recall from the introduction that Radkevich (2010) also argued that the three cases Locative, Allative and Ablative are internally complex, being composed of a feature denoting 'location', and a feature bundle containing further information about the presence or absence of motion to or from the location, $[ \pm$ motion], and whether or not that location is the source of any motion, $[ \pm$ source $]$. She observed that the feature bundle [-motion + source] is semantically incoherent, and therefore impossible. Consequently the cases can be arranged in the chart in (7). I call this the Allative-centred analysis because the Allative case sits between the Locative and Ablative cases. Like the Locative-centred analysis, the Allative-centred analysis is able to account for the Kunimaipa data, repeated in (6).

(6)

$$
\text { Kunimaipa cases }
$$

\begin{aligned} & \hline Kunimaipa \\ & \hline$-t i \quad$ Allative \\ &- ha Locative \\ & -ha-nanga Ablative \\ & -nanga Instr. \\ & \hline\end{aligned}

(7)

\section{Feature chart for the Allative-centred analysis}

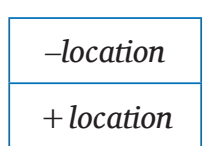

\begin{tabular}{|l|l|c|}
\cline { 3 - 3 } \multicolumn{2}{l|}{} & Instr. \\
\hline Locative & Allative & Ablative \\
\hline
\end{tabular}

\begin{tabular}{|c|c|}
\hline -motion & + motion \\
\hline -source & + source \\
\hline
\end{tabular}

Radkevich (2010) adopts the feature bundle [-location -motion -source] for the Instrumental case, ${ }^{2}$ but I will give it the bundle $[+$ location + source $]$, for the same reasons I did in the

2 It is unclear where this set of features comes from. Radkevich writes that she adopts the feature bundle for the Instrumental case as proposed by Calabrese 2008 (Radkevich 2010: 101), which she states is [-source -motion -location] (Radkevich 2010: 105). However, Calabrese gives the feature bundle for Instrumental as [ + peripheral -source + location + motion] (Calabrese 2008: 171). 
Locative-centred analysis. We can now analyse the exponents the Allative-centred analysis must adopt to account for the Kunimaipa data, which are given in (8).

$$
\text { Vocabulary Items for Kunimaipa in the Allative-centred analysis }
$$

\begin{tabular}{rll}
\hline Kunimaipa & & \\
\hline$[+$ location + motion - source $]$ & $\Leftrightarrow$ & -ti \\
{$[+$ motion + source $]$} & $\Leftrightarrow$ & -nanga \\
{$[+$ location $]$} & $\Leftrightarrow$ & -ha
\end{tabular}

Kunimaipa's Allative morpheme - $t i$ is a portmanteau in the Allative-centred analysis, realising [+location + motion-source]. As the morpheme -ha appears in the morphology of both the Locative and Ablative suffixes, it spells out their shared feature [+location]. The morpheme -nanga appears in both the Ablative and Instrumental cases; it must expone their shared features $[+$ motion + source $]$. $^{3}$

In this arrangement of the cases, Locative and Allative share a property; that of not denoting a source location, and Allative and Ablative share a property; that of denoting locations to or from which motion occurs. The Locative and Ablative cases have no property but 'location' in common. The Allative-centred analysis thus accounts for the syncretisms in (1) with the exponents in $(9)(m o t=$ motion $)$.

$$
\text { Exponents for the languages in (1) in the Allative-centred analysis }
$$

\begin{tabular}{|c|c|c|c|c|c|c|c|c|c|}
\hline \multicolumn{3}{|c|}{ Plains Cree } & \multicolumn{4}{|c|}{ Palaihnihan } & \multicolumn{3}{|c|}{ Bunganditj } \\
\hline$[+l o c]$ & $\Leftrightarrow$ & $-\mathrm{ikh}$ & {$[+l o c$} & $+m o t-s o u]$ & $\Leftrightarrow$ & $-\mathrm{t}-$ & {$[+l o c+s o u]$} & $\Leftrightarrow$ & -an \\
\hline & & & & {$[+l o c]$} & $\Leftrightarrow$ & $-\mathrm{m}-$ & {$[+l o c]$} & $\Leftrightarrow$ & $-\mathrm{u}$ \\
\hline
\end{tabular}

A third logically possible arrangement of the cases can be seen in the chart in (11). I call this the Ablative-centred analysis because the Ablative case sits between the Locative and Allative cases. The feature [ \pm source] from the Allative-centred analysis has now been replaced with [ \pm goal]; the analogous feature bundle [-motion + goal] is semantically incoherent and therefore impossible. For want of a better alternative, I have adopted the [-goal] counterpart of Radkevich's feature bundle for the Instrumental case: [-location -motion -goal].

3 If we retained Radkevich's feature bundle for the Instrumental case, the Allative-centred analysis could not explain the morpheme -nanga because with Radkevich's feature bundle, the Instrumental and Ablative cases have no feature in common. Radkevich 2010 appeals to Calabrese's 2008 impoverish-and-repair strategy to explain cases of syncretism between the locative and non-locative inherent cases. Calabrese 2008 argues that impoverishment is followed by feature filling, whereby a feature that has been deleted is replaced by the same feature with the opposite value, à la Noyer 1998. Thus, in a feature bundle $[+F+G]$, the targeted feature $[+F]$ is deleted and replaced by $[-\mathrm{F}]$. The exponent for $[-\mathrm{F}+\mathrm{G}]$ is then inserted, resulting in syncretism between the feature bundles $[+F+G]$ and $[-F+G]$ (Radkevich 2010: 103).

An analysis dependent on impoverishment or impoverishment-and-repair must be motivated because both are more complex than an analysis dependent on underspecification. This is why: If a terminal node that hosts the features [F G] is uniformly realised by an exponent $\mathrm{X}$ that is known to realise only the feature [F], an underspecification account will capture the data with the rule of exponence $[\mathrm{F}] \Leftrightarrow \mathrm{x}$. For an impoverishment account to be invoked, a terminal node that hosts the features [F G], must be uniformly realised by an exponent $\mathrm{x}$ that is known to realise only the feature $[\mathrm{F}]$, despite the fact that another exponent $\mathrm{Y}$ that is known to realise the features [F G] exists $([\mathrm{F}] \Leftrightarrow \mathrm{X} ;[\mathrm{F} \mathrm{G}] \Leftrightarrow \mathrm{Y})$. By the Maximal Subset Principle this should be impossible, and so impoverishment of the feature $\mathrm{G}$ is motivated ( $\mathrm{G} \rightarrow \xi /[\mathrm{F}]$ ). If an impoverishment-and-repair account is to be invoked, a terminal node that hosts the features [F G] must be uniformly realised by an exponent $\mathrm{z}$ that is known to realise the features [F H] , despite the existence of two other exponents $\mathrm{X}$ and $\mathrm{Y}$ that are known to realise the features [F] and [F G] respectively ([F] $\Leftrightarrow \mathrm{X} ;[\mathrm{F} \mathrm{G}] \Leftrightarrow \mathrm{Y} ;[\mathrm{FH}] \Leftrightarrow \mathrm{Z}$ ). By the Maximal Subset Principle this should be impossible, and so both the impoverishment of the feature $\mathrm{G}$ and insertion of the feature $\mathrm{H}$ are motivated (G $\rightarrow \xi /\left[\mathrm{F} \_\right]$and $\varnothing \rightarrow$ $\left.\mathrm{H} /\left[\mathrm{F} \_\right]\right)$.

Neither Calabrese 2008 nor Radkevich 2010 motivate the impoverish-and-repair strategy (unlike Noyer 1998 and Harbour 2003, who do) for syncretisms between the locative and non-locative cases. In the specific case we are concerned with here, an impoverish-and-repair strategy will only rescue the Kunimaipa data if impoverish-andrepair applies to all the features in one of the bundles, as the Ablative case realises the features $[+$ location + motion + source], while Instrumental case realises the features [-location-motion-source]. 


\begin{aligned} & \hline Kunimaipa \\ & \hline$-t i \quad$ Allative \\ &- ha Locative \\ & -ha-nanga Ablative \\ & -nanga Instr. \\ & \hline\end{aligned}

Feature chart for the Ablative-centred analysis

\begin{tabular}{|l|}
\hline -location \\
\hline +location \\
\hline
\end{tabular}

\begin{tabular}{|c|c|c|}
\hline Instr. & & \\
\hline Locative & Ablative & Allative \\
\hline
\end{tabular}

\begin{tabular}{|c|c|}
\hline -motion & + motion \\
\hline & + goal \\
\hline
\end{tabular}

In this arrangement of the cases, Locative and Ablative share a property; that of not denoting a goal location, while Allative and Ablative denote locations to or from which motion occurs. Now the Locative and Allative cases have no property but 'location' in common.

Exponents for the languages in (1) in the Ablative-centred analysis

\begin{tabular}{|c|c|c|c|c|c|c|c|}
\hline Plains Cree & \multicolumn{3}{|c|}{ Palaihnihan } & \multicolumn{4}{|c|}{ Bunganditj } \\
\hline$[+l o c] \Leftrightarrow \quad-\mathrm{ikh}$ & {$[+$ loc + goal $]$} & $\Leftrightarrow$ & $-t-$ & {$[+l o c$} & + mot -goal] & $\Leftrightarrow$ & -an \\
\hline & {$[+l o c]$} & $\Leftrightarrow$ & $-m-$ & & {$[+l o c]$} & $\Leftrightarrow$ & $-\mathrm{u}$ \\
\hline
\end{tabular}

While the Ablative-centred analysis can account for the syncretisms in (1) with the exponents in (12), it is unable to account for the Kunimaipa data. The exponents the Ablative-centred analysis must adopt to account for the Kunimaipa data are given in (13).

Vocabulary Items for Kunimaipa in the Ablative-centred analysis

\begin{tabular}{rlll}
\hline Kunimaipa & & \\
\hline$[+$ location + motion + goal $]$ & $\Leftrightarrow$ & -ti \\
{$[$-goal $]$} & $\Leftrightarrow$ & -nanga \\
$?$ & $\Leftrightarrow$ & -ha \\
\hline
\end{tabular}

The morpheme $-t i$ is again a portmanteau, spelling out $[+$ location + motion + goal $]$. Since the Ablative and Instrumental cases share the feature [-goal] in the Ablative-centred analysis, -nanga spells out [-goal]. This leaves the morpheme -ha. This appears in the morphology of both the Locative and Ablative cases. They share two features, [+location] and [-goal]. The exponent -ha cannot spell out [+location] because the Locative case would then be realised as -ha-nanga, contrary to fact; it also cannot spell out [+location -goal] either, as then the Ablative case marker would simply be -ha, again contrary to fact. It is therefore impossible to explain the morpheme distribution of Kunimaipa in the Ablative-centred analysis.

In conclusion, there are three logically possible ways in which the locative cases can be ordered. Two of the analyses can explain the Kunimaipa data; the one in which the Locative case is flanked by the Ablative and Allative cases, with the Instrumental case sharing the features [+ source-goal] with the Ablative, and the one in which the Allative case is flanked by the 
Locative and Ablative cases, with the Instrumental case sharing the features $[+$ motion + source $]$ with the Ablative.

\section{Binary vs Privative features: Occam's Razor}

In this section I present my final argument which identifies the Locative-centred analysis as the optimal one, namely that the features that underlie the inherent cases are privative, rather than binary. My argument is a manifestation of Occam's Razor. Occam's Razor is a law of parsimony. In essence, it says that when presented with competing hypotheses that make the same predictions, one should select the hypothesis with the fewest assumptions. In the same spirit then, if two analyses both account for a body of attested data, we should adopt the simpler analysis. Binary and privative features present an excellent example of this. If it is possible to account for the attested and unattested syncretism patterns of the locative cases with privative features, then we should prefer this over an analysis which accounts for the same data with binary features. ${ }^{4}$

The Locative-, Allative- and Ablative-centred analyses can all be realised with privative features. Replacing the binary features with their privative counterparts has one important theoretical consequence; namely that certain syncretisms will be predicted to be impossible. This is because rules of exponence cannot refer to the absence of a feature, whereas they can refer to features with a negative value. Ergo, a theory with privative features is more restrictive than one with binary features. Consider the abstract feature chart for the locative cases in (14).

\section{Abstract binary feature chart}

\begin{tabular}{|c|c|c|c|}
\hline \multirow[t]{3}{*}{$+F$} & Case $\alpha$ & Case $\beta$ & Case $\gamma$ \\
\hline & $-G$ & \multicolumn{2}{|c|}{$+G$} \\
\hline & \multicolumn{2}{|c|}{$-H$} & $+H$ \\
\hline
\end{tabular}

This chart makes one critical prediction: any two cases can be syncretic to the exclusion of the third. For example, if the exponent for the syncretic cases was always less-specified than the exponent for the non-syncretic case, ${ }^{5}$ the $\alpha$ and $\beta$ cases would show syncretism with exponents for $[+\mathrm{F}+\mathrm{H}]$ and $[+\mathrm{F}]$; the $\alpha$ and $\gamma$ cases would show syncretism with exponents for $[+\mathrm{G}-\mathrm{H}]$ and $[+\mathrm{F}]$; and the $\beta$ and $\gamma$ cases would show syncretism with exponents for $[+\mathrm{F}-\mathrm{G}]$ and $[+\mathrm{F}]$ (15).

Exponents for the syncretism of two cases to the exclusion of the third

\begin{tabular}{|c|c|c|c|c|c|c|c|c|}
\hline \multicolumn{3}{|c|}{ Syncretism: $\alpha$ and $\beta$} & \multicolumn{3}{|c|}{ Syncretism: $\alpha$ and $\gamma$} & \multicolumn{3}{|c|}{ Syncretism: $\beta$ and $\gamma$} \\
\hline$[+\mathrm{F}+\mathrm{H}]$ & $\Leftrightarrow$ & $\mathrm{X}$ & {$[+\mathrm{G}-\mathrm{H}]$} & $\Leftrightarrow$ & $\mathrm{X}$ & {$[+\mathrm{F}-\mathrm{G}]$} & $\Leftrightarrow$ & $\mathrm{X}$ \\
\hline$[+\mathrm{F}]$ & $\Leftrightarrow$ & $\mathrm{Y}$ & {$[+\mathrm{F}]$} & $\Leftrightarrow$ & Y & {$[+\mathrm{F}]$} & $\Leftrightarrow$ & $\mathrm{Y}$ \\
\hline
\end{tabular}

Now consider the cases suffixes of the following three Papuan languages of New Guinea: Iatmul, Kewa and Dani (16).

4 Note that if a privative analysis is successful in the case domain, this does not present an argument against binary features more generally; in other domains a privative analysis may be unsuccessful, rendering a binary analysis preferred (see, for example, Harbour 2007a; 2014 for a binary analysis of number features, and Harbour 2016 for a binary analysis of person features, which contrasts with Ackema \& Neeleman 2018, who argue for privative person features).

5 An anonymous reviewer observes that a characteristic of elsewhere forms is that they have a broad and frequently heterogeneous distribution. However, this is a tendency, not an absolute. The definition of an elsewhere form is a morpheme that realises the smallest number of relevant features. It is perfectly possible that an elsewhere form could appear only once, if all the other feature bundles are exponed by more highly-specified exponents. For example, for the feature chart in (14), the exponents $[+\mathrm{F}-\mathrm{H}] \Leftrightarrow \mathrm{X}$ and $[+\mathrm{F}] \Leftrightarrow \mathrm{Y}$ will result in the elsewhere form, Y, appearing only once (for the $\gamma$ case), while the most highly-specified form, $\mathrm{X}$, appears twice. 


\begin{tabular}{llll}
\hline & Iatmul & Kewa & Dani \\
\hline ALLATIVE & $-(\eta k) a t$ & -para & $-m a$ \\
LOCATIVE & $-m p a$ & -para & $-m a$ \\
ABLATIVE & $-m p a$ & -para & -nen \\
INSTRUMENTAL & $-m p a$ & $-m e ́$ & -nen \\
\hline
\end{tabular}

Each of these languages demonstrates a different pattern of syncretism. Iatmul presents an instance of Locative-Ablative-Instrumental syncretism; Kewa's syncretism is with the three locative cases, Allative-Locative-Ablative; and Dani shows two syncretisms, Locative-Allative and Ablative-Instrumental. Setting aside Instrumental because it's not a locative case, one pattern of syncretism is conspicuous by its absence: Ablative-Allative. This Papuan data is consistent with Radkevich 2010; in her survey of 111 languages, Radkevich found only two types of syncretism between the locative cases: Locative-Allative to the exclusion of Ablative, and Locative-Ablative to the exclusion of Allative (Radkevich 2010: 86).

The Locative-centred privative analysis accounts for the data in (16), rendering it superior by Occam's Razor to its binary counterpart. Moreover, it correctly predicts the absence of AblativeAllative syncretisms. I give its feature chart in (17), where the feature [-location] has been replaced by the feature [entity]. This reflects the fact that the Instrumental case marks a tool and not a location. As far as I'm aware, there is no language in which a location can simultaneously be an entity, so these are mutually exclusive features, hosted by the Property node.

Locative-centred privative feature chart

\begin{tabular}{|c|}
\hline entity \\
\hline location \\
\hline
\end{tabular}

\begin{tabular}{|c|c|c|}
\hline Instr. & \multicolumn{2}{|c}{} \\
\hline Ablative & Locative & Allative \\
\hline
\end{tabular}

source

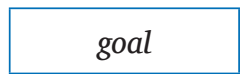

To accompany this feature chart, we need a tree. Smith et al (2019) and Zompì (2019) argue that the inherent cases are built on top of the structural cases: [[[Unmarked] Marked] Inherent]. Radkevich (2010) argues that the features of the inherent cases belong to daughter nodes of Inherent, called Property and Motion; Property hosts the feature [ \pm location] and Motion hosts [ \pm motion] and $[ \pm$ source $] .{ }^{6}$ Across the 111 languages that Radkevich (2010) surveyed, Property morphemes were uniformly closer to the noun than Motion morphemes. Radkevich needs Property and Motion to be sisters because of the specific instantiation of non-terminal node insertion that she adopts; since I favour a spanning account (Svenonius 2012), I will assume that the Property and Motion nodes each c-command the Marked and Unmarked nodes (18).

$$
\text { The tree structure for case morphology }
$$

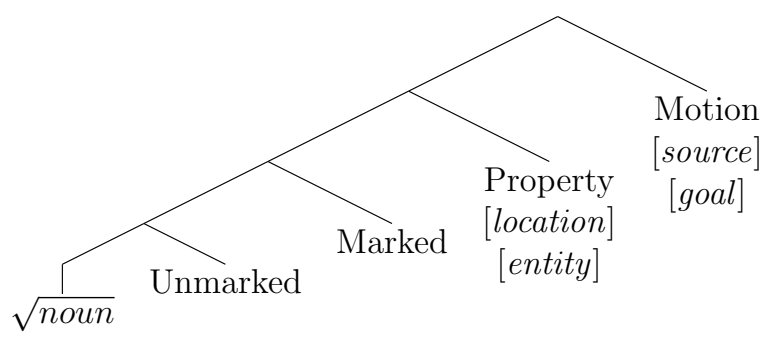


Given the structure in (18), the exponents for Iatmul, Kewa and Dani are as given below (where $\mathrm{U}=$ Unmarked, $\mathrm{M}=$ Marked, and $\mathrm{P}=$ Property) (19).

The Iatmul, Kewa and Dani exponents

\begin{tabular}{|c|c|c|c|c|c|c|c|c|}
\hline \multicolumn{3}{|c|}{ Iatmul } & \multicolumn{3}{|c|}{ Kewa } & \multicolumn{3}{|c|}{ Dani } \\
\hline [loc goal] & $\Leftrightarrow$ & -(yk)ət & [U M loc] & $\Leftrightarrow$ & -para & [P sou $]$ & $\Leftrightarrow$ & -nen \\
\hline$[\mathrm{P}]$ & $\Leftrightarrow$ & -mpa & [U M] & $\Leftrightarrow$ & -mé & {$[\mathrm{P}]$} & $\Leftrightarrow$ & $-\mathrm{ma}$ \\
\hline
\end{tabular}

The Iatmul syncretism between the Instrumental, Ablative and Locative cases is captured with an exponent that spells out the span of [location] and [goal] features, and an elsewhere exponent for the inherent cases, spelling out $\mathrm{P}$, the Property node without any features. Since Foley reports that subjects and objects are primarily marked with verbal agreement rather than case suffixes (Foley 1986: 94), I assume that the Unmarked and Marked features of the structural cases are not exponed in Iatmul. Kewa's syncretism in the locative cases is captured with an exponent that spells out the span of Unmarked, Marked and [location]. A true elsewhere exponent spells out the span of the Unmarked and Marked features; -mé expones the Ergative and Causative cases as well as the Instrumental case in Kewa (Foley 1986: 93). Dani's double syncretism is captured with an exponent that spells out the span of the Property node and [source] feature, and an elsewhere exponent for the Property node. The Locative-centred privative analysis also captures the Kunimaipa data mentioned earlier, with the same three exponents in (4), but with privative features instead of positive ones.

Crucially, the Locative-centred privative analysis excludes an Ablative-Allative syncretism unless that syncretism also includes Locative. Since the only feature Ablative and Allative share is [location], they can only be syncretic if they are both realised by an underspecified exponent [location] $\Leftrightarrow \mathrm{X}$. Since [location] is the only feature that belongs to the Locative case, this exponent will result in syncretism of Locative as well.

I will now show that the Allative-centred and Ablative-centred privative analyses are unable to account for the syncretisms in (16), and furthermore that they make incorrect predictions about possible and impossible syncretisms.

In the Allative-centred privative analysis, the Instrumental case bears the feature [entity] instead of [-location]. The Locative, Allative and Ablative cases all bear the feature [location]; Allative and Ablative also bear [motion]; while Ablative and Instrumental also bear [source] (20).

Allative-centred privative feature chart

\begin{tabular}{|c|}
\hline entity \\
\hline location \\
\hline
\end{tabular}

\begin{tabular}{|c|c|c|}
\cline { 3 - 3 } \multicolumn{2}{c|}{} & Instr. \\
\hline Locative & Allative & Ablative \\
\hline
\end{tabular}

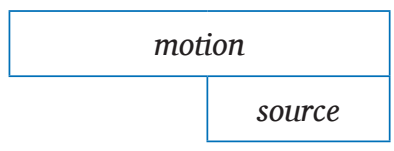

In this analysis, the Kewa data is accounted for with two exponents, one for [entity] and the other for [location]. But the Iatmul and Dani data cannot be explained in the Allative-centred privative analysis. The Iatmul syncretism cannot be explained because there is no set of features unique to the Allative case or shared exclusively by the Instrumental, Locative and Ablative cases that would allow for the Instrumental-Ablative-Locative syncretism to be captured. Likewise, there is no set of features unique to either the Allative and Locative cases or the Ablative and Instrumental cases to capture the two syncretisms of Dani. In addition to these problems, the Allative-centred privative analysis predicts the possibility of an Allative-Ablative syncretism to the exclusion of Locative, which is unattested, since the Allative and Ablative cases share the feature [motion]. 
The Ablative-centred privative analysis bumps into similar problems. I give its feature chart in (21).

Ablative-centred privative feature chart

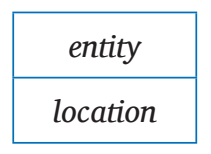

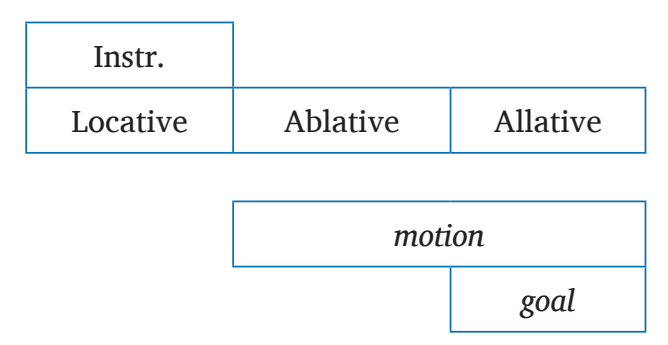

The Ablative-centred privative analysis can account for the Iatmul data with two exponents; one for [location motion goal], and an elsewhere exponent. The Kewa data is captured with an exponent for [entity] and a second for [location]. But the two syncretisms in Dani are impossible to account for in the Ablative-centred privative analysis, as neither the Locative and Allative cases nor the Instrumental and Ablative cases share a unique set of features. Like its Allativecentred privative counterpart, the Ablative-centred privative analysis predicts the possibility of an Allative-Ablative syncretism to the exclusion of the Locative, which is unattested, since these cases share the feature [motion].

Since the Locative-centred privative analysis is the only analysis that can account for the syncretisms found in Iatmul, Kewa and Dani, and since the Locative-centred privative analysis is the only analysis that correctly predicts the impossibility of a syncretism between the Ablative and Allative cases to the exclusion of the Locative, it should, by Occam's Razor, be favoured until data it cannot account for surfaces.

\section{Conclusion}

In conclusion, I have shown that of the three logically possible arrangements of the Locative, Allative and Ablative cases, the one that best accounts for the data is the Locative-centred analysis, where Locative is flanked by the Ablative and Allative cases. Furthermore, I have demonstrated that the Locative-centred analysis with privative features has the best empirical coverage, as it is the only analysis that predicts the possibility of three types of attested syncretism (Ablative-Locative-Allative; Ablative-Locative; and Locative-Allative) but not the unattested (Ablative-Allative).

Several questions remain for future research. The Instrumental case's feature bundle [entity source] prompts us to ask what cases are denoted by the [entity] and [entity goal] feature bundles; the features [location] and [entity] prompt us to ask if other Property features are possible.

\section{Acknowledgements}

I am indebted to three anonymous reviewers and the following, for many helpful comments on and discussion of the ideas presented here: Jonathan Bobaljik, Noam Faust, Daniel Harbour, Luisa Martí, Tom McFadden, Ad Neeleman, Jeff Parrott, Linnaea Stockall, Coppe van Urk, and participants of the workshop On the place of case in grammar (Crete, 2018). All errors are my own.

\section{Competing interests}

The author has no competing interests to declare.

\section{Author affiliation}

Jane Middleton (D) orcid.org/0000-0003-1657-276X

University College London, 2 Wakefield Street, London, WC1N 1PF, GB 


\section{References}

Ackema, P. \& A. Neeleman. 2018. Features of Person. DOI: https://doi.org/10.7551/ mitpress/11145.001.0001

Blake, Barry J. 2003. The Bunganditj (Buwandik) language of the Mount Gambier Region. Sydney: The Australian National University Press.

Bobaljik, J. D. 2012. Universals in comparative morphology: Suppletion, superlatives, and the structure of words. MIT Press. DOI: https://doi.org/10.7551/mitpress/9069.001.0001

Broadbent, Sylvia M. 1964. The Southern Sierra Miwok Language. Berkeley and Los Angeles: University of California Press.

Caha, P. 2009. The nanosyntax of case. PhD Thesis. University of Tromsø.

Calabrese, Andrea. 2008. On absolute and contextual syncretism: remarks on the structure of case paradigms and on how to derive them. Inectional identity 18(156-205).

Chomsky, N. 1993. Lectures on government and binding: The Pisa lectures (No. 9). Walter de Gruyter. DOI: $h$ ttps://doi.org/10.1515/9783110884166

Chomsky, N. 1995. The minimalist program (Vol. 28). Cambridge, MA: MIT press.

Dahlstrom, Amy. 1991. Plains Cree Morphosyntax. New York: Garland.

Foley, William. 1986. The Papuan languages of New Guinea. Cambridge University Press.

Halle, Morris \& Alec Marantz. 1993. Distributed morphology and the pieces of inection.

Harbour, D. 2003. The Kiowa case for feature insertion. Natural Language \& Linguistic Theory 21(3). 543578. DOI: https://doi.org/10.1023/A:1024196621352

Harbour, D. 2007a. Morphosemantic Number: From Kiowa Noun Classes to UG Number Features (Vol. 69). Springer Science Business Media. DOI: https://doi.org/10.1007/978-1-4020-5038-1

Harbour, D. 2007b. A program for case features. Handout, Queen Mary University of London.

Harbour, D. 2014. Paucity, abundance, and the theory of number. Language, 185-229. DOI: https://doi. org/10.1353/lan.2014.0003

Harbour, D. 2016. Impossible persons (Vol. 74). MIT Press. DOI: https://doi.org/10.7551/ mitpress/9780262034739.001.0001

Harley, H. 2008. When is a syncretism more than a syncretism? Impoverishment, metasyncretism, and underspecification. Phi theory: Phi-features across modules and interfaces, 251-294.

Jakobson, Roman. 1962. Beitrag zur allgemeinen Kasuslehre: Gesamtbedeutungen der russischen Kasus. In Selected writings 2. 23-71. Mouton, The Hague.

Kiparsky, P. 1973. "Elsewhere" in phonology.

Noyer, R. 1998. Impoverishment theory and morphosyntactic markedness. In Steven G. Lapointe, Diane K. Brentari \& P. M. Farrell (eds.), Morphology and its Relation to Morphology and Syntax, 264-286. Stanford: CSLI.

Radkevich, N. 2010. On location: The structure of case and adpositions. Storrs, CT: University of Connecticut.

Robins, R. H. 1958. The Yurok language: grammar, texts, lexicon. Berkeley and Los Angeles: University of California Press.

Smith, P., B. Moskal, T. Xu, J. Kang \& J. Bobaljik, 2019. Case and number suppletion in pronouns. Natural Language \& Linguistic Theory 37(3). 1029-1101. DOI: https://doi.org/10.1007/s11049-018-9425-0

Sridhar, S. N. 1990. Kannada. London and New York: Routledge.

Zompì, S. 2019. Ergative is not inherent: Evidence from *ABA in suppletion and syncretism. Glossa: $a$ journal of general linguistics, 4(1). DOI: https://doi.org/10.5334/gigl.816
TO CITE THIS ARTICLE: Middleton, Jane. 2021. Developing the feature inventory of the inherent cases. Glossa: a journal of general linguistics 6(1): 68. 1-11. DOI: https://doi. org/10.5334/gjgl.933

Submitted: 04 March 2019 Accepted: 30 April 2020 Published: 20 May 2021

\section{COPYRIGHT:}

(c) 2021 The Author(s). This is an open-access article distributed under the terms of the Creative Commons Attribution 4.0 International License (CC-BY 4.0), which permits unrestricted use, distribution, and reproduction in any medium, provided the original author and source are credited. See http:// creativecommons.org/ licenses/by/4.0/.

Glossa: a journal of general linguistics is a peer-reviewed open access journal published by Ubiquity Press. 